January 2009

\title{
Antitrust Summary Judgment and the Quick Look Approach
}

Edward Brunet

\section{Recommended Citation}

Edward Brunet, Antitrust Summary Judgment and the Quick Look Approach, 62 SMU L. REV. 493 (2009) https://scholar.smu.edu/smulr/vol62/iss2/4

This Article is brought to you for free and open access by the Law Journals at SMU Scholar. It has been accepted for inclusion in SMU Law Review by an authorized administrator of SMU Scholar. For more information, please visit http://digitalrepository.smu.edu. 


\title{
Antitrust Summary Judgment AND THE Quick LOOK Approach
}

\author{
Edward Brunet*
}

Three methodological shortcuts potentially streamline antitrust litigation. The availability of the per se approach provides a time-tested way to avoid conventional trials where illegality is obvious. However, the seeming collapse of per se rules in modern antitrust cases creates a need for some type of abbreviated assessment of economic impact of alleged restraints. The quick look approach provides a means for a truncated pretrial evaluation of competitive effect. At the same time, a third potential shortcut, summary judgment, appears to be readily available in antitrust cases after a period of some skepticism toward its use and appears to also interject pretrial assessment of economic effect into a case. This article first describes the quick look and antitrust summary judgment, and then explores integration of the two complementary concepts. Although I find that only a few cases grant summary judgment using the quick look, I posit that these two different shortcuts are capable of efficient synergy in the same case. The paper paradoxically concludes that courts appear skeptical of the quick look's vague contours and, yet, seem willing to employ summary judgment, a similar procedure.

\section{TABLE OF CONTENTS}

INTRODUCTION

I. A SKETCH OF THE ORIGIN AND NATURE OF THE QUICK LOOK APPROACH .....................

A. The Quick Look as a Means to Per Se

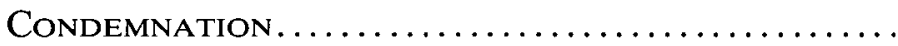

B. The Quick Look Rule of Reason: A Means or

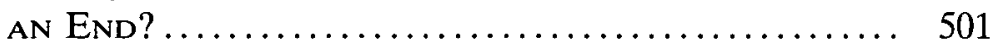

II. THE ROLE OF SUMMARY JUDGMENT IN ANTITRUST LITIGATION ..................... 504

A. A Theory of a Transsubstantive Rule $56 \ldots \ldots .504$

B. The Practical Meaning of Transsubstantive Antitrust Summary Judgment: No Special Latitude Given to the Antitrust Nonmovant ... 505

1. The Inconsistent Poller Years: 1962-1985 ........ 505

2. Matsushita and the Demise of the Poller Dictum... 509

3. A Rule 56-Friendly Reading of Kodak ........... 511

* Henry J. Casey Professor of Law, Lewis \& Clark Law School. I thank Casey Charles, Sara Werboff, and Wendy Hitchcock for their valuable research assistance. 
4. Antitrust Summary Judgment is Alive, Diverse, and Working .................................

a. Antitrust Affirmative Defenses........... 515

b. Defense Attacks on Elements of the Plaintiff's Prima Facie Case ..................... 516

III. CONNECTING THE PROCEDURAL DOTS? THE APPLICATION OF THE QUICK LOOK APPROACH TO SUMMARY JUDGMENT ....................

A. The Importance of Texaco Inc. v. Dagher .......

B. Integrating Summary Judgment and the Quick LoOK .................................. 518

C. The Use of the Quick Look at the Federal Trade Commission ........................... 521

IV. CONCLUSION $\ldots \ldots \ldots \ldots \ldots \ldots \ldots \ldots \ldots \ldots \ldots \ldots, 523$

\section{INTRODUCTION}

NTITRUST litigation, frequently characterized as constituting
complex or big cases, ${ }^{1}$ seemingly begs for some sort of method-
ological shortcut. ${ }^{2}$ The history of efforts to streamline or simplify antitrust cases is both rich and lengthy. Judge Taft's seminal United States v. Addyston Pipe \& Steel Co. opinion, written in 1897, just seven years after the passage of the Sherman Act, expressed an acute concern for eschewing overly complicated and ambiguous trials of antitrust cases by cautioning that antitrust analysis should avoid setting "sail on a sea of doubt" and set forth a sophisticated method for analyzing antitrust issues that, while capable of abuse, originated in a desire to more efficiently adjudicate antitrust cases. ${ }^{3}$ Judge Taft's method provided a shortcut to illegality if an alleged restraint could be characterized as clearly restraining commerce ${ }^{4}$ and set forth a sophisticated approach that facilitated the evolution of per se rules and the rule of reason. ${ }^{5}$

Justice Brandeis's landmark articulation of the rule of reason in Chi-

1. See, e.g., Fed. Judicial Ctr., Manual for Complex Litigation 519 (4th ed. 2004) (stating that antitrust litigation can "involve voluminous documentary and testimonial evidence, extensive discovery, complicated legal, factual, and technical (particularly economic) questions"); 2 Phillip Areeda et al., Antrtrust Law 79 (2d ed. 2000) (referring to the "fearful dimensions" of antitrust litigation).

2. See, e.g. generally, Edward Brunet, Streamlining Antitrust Litigation by "Facial Examination" of Restraints: The Burger Court and the Per Se-Rule of Reason Distinction, 60 WASH. L. REV. 1 (1984).

3. United States v. Addyston Pipe \& Steel Co., 85 F. 271, 283-84 (6th Cir. 1898), aff'd as modified, 175 U.S. 211 (1898); see also Thomas C. Arthur, Farewell to the Sea of Doubt: Jettisoning the Constitutional Sherman Act, 74 CAL. L. REv. 263, 271 (1986) (advocating the general use of Judge Taft's Addyston Pipe framework).

4. Addyston Pipe, 85 F. at 301.

5. See, e.g., Robert H. Bork, The Antrtrust Paradox 26 (1978) (describing Addyston Pipe as "one of the greatest, if not the greatest, antitrust opinions in the history of the law"); Brunet, supra note 2, at 22-23. 
cago Board of Trade v. United States, ${ }^{6}$ sometimes criticized as calling for an overly complex, multi-factor analysis, ${ }^{7}$ may have included its own shortcut. In reversing a trial court order invalidating the Call Rule of the defendant, Chicago Board of Trade, Justice Brandeis failed to remand the case for a full-blown trial and set forth a list of conclusions basically upholding the alleged restraint merely by a summary style of judicial analysis. ${ }^{8}$ This bold tour de force of judicial activism signaled the bench and bar that lengthy trials of antitrust cases might not be necessary where the court was willing to decide antitrust issues as a matter of law.

The classification of alleged restraints as either per se or rule of reason has dominated antitrust methodology for close to one hundred years. The shortcut of designating a restraint as per se efficiently eliminates the defendant's ability to introduce proof showing pro-competitive impact. ${ }^{9}$ In this sense, the per se label operates as a rule of evidence that excludes business justifications and makes antitrust litigation less costly. Similarly, an early, pretrial selection of a rule of reason approach facilitates antitrust litigation by allowing pro- and anti-competitive impact to be the focus of a case and creates an opportunity for granting defense motions for summary judgment.

Summary judgment represents another means of efficiently administering antitrust litigation. Rules of litigation procedure must integrate appropriately into antitrust methodology. In particular, motions for summary judgment provide a way to avoid costly and lengthy antitrust litigation and provide a means to anchor the per se approach in procedural orthodoxy. The party who advances a per se argument often moves for summary judgment. ${ }^{10}$ In contrast, the opposing party, who considers the rule of reason to apply, will typically combat summary judgment and argue that the issues should receive a full trial. Of course, defendants faced with antitrust claims often seek summary judgment and frequently succeed. ${ }^{11}$ Antitrust summary judgment, once thought to be inappropriate in Poller v. C.B.S., ${ }^{12}$ has matured into regular and everyday use

6. 246 U.S. 231 (1918).

7. See, e.g., Arthur, supra note 3 , at 303 (accusing Justice Brandeis of legitimizing big antitrust cases by his test, which makes "virtually all data relevant"); Brunet, supra note 2, at 14 (explaining that under Justice Brandeis's "broad approach," a factfinder must evaluate all the circumstances of the case).

8. See generally Peter C. Carstensen, The Content of the Hollow Core of Antitrust: The Chicago Board of Trade Case and the Meaning of the "Rule of Reason" in Restraint of Trade Analysis, 15 REs. L. \& ECON. 1, 35 (1992).

9. See, e.g., United States v. Trenton Potteries Co., 273 U.S. 392, 401 (1927) (holding that horizontal price fixing is per se illegal); United States v. Socony-Vacuum Co., 310 U.S. 150, 218-20 (1940) (same); N. Pac. Ry. Co. v. United States, 356 U.S. 1, 7-8 (1958) (holding that tying contracts are per se illegal where plaintiff proves defendant's market power).

10. See, e.g., Arizona v. Maricopa County Med. Soc'y, 457 U.S. 332, 336, 348 (1982). (upholding summary judgment and a per se analysis).

11. See, e.g., Clorox Co. v. Sterling Winthrop, Inc., 117 F.3d 50, 55 (2d Cir. 1997) (affirming summary judgment for defendant in an antitrust suit); Orson, Inc. v. Miramax Film Corp., 79 F.3d 1358, 1375 (3d Cir. 1996) (affirming summary judgment for defendant in an antitrust suit brought by a film exhibitor against a movie distributor).

12. 368 U.S. 464,473 (1962). 
through acceptance of a transformative summary judgment philosophy, the thinking that procedural rules should be applied the same way in every case, regardless of type of claim. ${ }^{13}$ Under such reasoning, summary judgment in complex antitrust cases has become possible despite critics who argue that summary judgments are granted far too readily in complex cases and constitute a temptation to avoid full litigation. ${ }^{14}$ Modern decisions and commentary reason that antitrust cases are ideal candidates for summary judgment because of concern that protracted litigation may chill competitive forces. ${ }^{15}$

With this background of uncertainty regarding the use of summary judgment in antitrust litigation and the history of controversial application of the per se and rule of reason labels, the so-called quick look approach originated. Born in a series of briefs to the United States Supreme Court in the $1980 \mathrm{~s},{ }^{16}$ the quick look methodology was essentially the effort of antitrust specialist litigators to articulate a sort of middle-ground, efficient way to avoid overly complex trials. The idea of the quick look might have evolved from Professor Phillip Areeda's observation that the rule of reason need not be overly lengthy and could be "applied in the twinkling of the eye."17

The 1980s and 1990s marked the rise of the quick look and the fall of the categorical method of antitrust classification that characterized each

13. See, e.g., Robert M. Cover, For James Wm. Moore: Some Reflections on a Reading of the Rules, 84 YALE L.J. 718, 740 (1975).

14. See, e.g., Arthur R. Miller, The Pretrial Rush to Judgment: Are the "Litigation Explosion," "Liability Crisis," and Efficiency Clichés Eroding Our Day in Court and Jury Trial Commitments?, 78 N.Y.U. L. Rev. 982, 984-85 (2003) (questioning increased use of summary judgment); Patricia M. Wald, Summary Judgment at Sixty, 76 TEx. L. REv. 1897, 1897-98 (1998) (critiquing the impact of increased use of summary judgment).

15. See, e.g., Geneva Pharms. Tech. Corp. v. Barr Labs., Inc., 386 F.3d 485, 495 (2d Cir. 2004) (asserting that summary judgment "is an essential tool in the area of antitrust law because it helps avoid wasteful and lengthy litigation that may have a chilling effect on procompetitive market forces"); Int'l Healthcare Mgmt. v. Haw. Coal. for Health, 332 F.3d 600,604 (9th Cir. 2003) (affirming summary judgment in an antitrust conspiracy case and concluding that "summary judgment is still appropriate in certain cases" despite factual complexity quoting County of Toutumne v. Sonoma Cmty. Hosp., 236 F.3d 1148, 1154 (9th Cir. 2001)); accord William W. Schwarzer, Summary Judgment and Case Management, 56 ANTITRUST L.J. 213, 222 (1987) (stating that "[a]ntitrust cases present the paradigm for the use of summary judgment in complex litigation").

16. See, e.g., Brief for the United States as Amicus Curiae at 8, 20, Arizona v. Maricopa County Med. Soc'y, 457 U.S. 332 (1982) (No. 80-419), 1981 WL 390409, at *8, *20 (describing the "initial inquiry" in a horizontal price fixing claim involving maximum prices as "either a 'quick look' to determine the applicability of the per se rule or a limited rule of reason inquiry" and explaining that "this preliminary scrutiny or 'quick look' should be limited to ascertaining whether the proponents of the agreement have identified significant procompetitive effects achieved through integration of productive capacity that are unattainable in the absence of the agreement"); Brief for the United States as Amicus Curiae Supporting Reversal at 7, Nw. Wholesale Stationers, Inc. v. Pac. Stationery \& Printing Co., 472 U.S. 284 (1985) (No. 83-1368), 1984 WL 565685, at *7 (arguing against application of a per se approach "without the sort of 'quick look' that the Court has required in other areas as a starting point for analysis under Section 1").

17. Phillip Areeda, The "Rule of Reason" in Antitrust Analysis: General Issues 37-38 (1981). It should be noted that this 1981 article was published after the 1980 reference to the quick look approach in the amicus brief for the United States filed in Maricopa County. 
restraint as either per se or rule of reason. Led by Justice Stevens, a series of Supreme Court antitrust decisions appeared to merge or collapse the per se and rule of reason approaches into one general continuum. ${ }^{18}$ Antitrust attorneys and agencies engaged in the quick look approach. The idea appeared to dovetail neatly with the emphasis of Sylvania that some sort of economic evaluation should occur in every antitrust case. ${ }^{19}$ A fast, informal examination of the pro- and anti-competitive considerations of the allegedly illegal restraint was essential in every antitrust case, allowing the quick look to be either the first step of a longer rule of reason process or the single step of a shortcut method leading to a per se result. Judge Posner's 1984 use of a quick look in General Leaseways, Inc. v. National Truck Leasing Ass'n provided an early example of the quick look.20 Judge Posner's per se conclusion was reached by determining "[whether] the elimination of competition is apparent on a quick look" and "without undertaking the kind of searching inquiry that would make the case a Rule of Reason case." 21

The decade of the 1980s saw courts and agencies flirting with adoption of the quick look method. While the Supreme Court never expressly adopted the quick look as a methodology, it came very close in a number of cases. The NCCA v. Board of Regents of the University of the Oklahoma decision engaged in a careful analysis of efficiencies in a context that may have called for per se application. ${ }^{22}$ In Northwest Wholesale, Justice Brennan required a "threshold determination" of the alleged restraint in a case with a summary judgment record. ${ }^{23}$ In Catalano, Inc. $v$. Target Sales, Inc., the Court found a conspiracy to deny short term credit to be per se illegal but took care to summarily analyze possible efficiency justifications. ${ }^{24}$ In Arizona v. Maricopa County Medical Society, the Court's per se analysis considered both the positive and negative implications of the alleged horizontal restraint. ${ }^{25}$

To some, the 1999 California Dental ${ }^{6}$ opinion marked the Court's rejection of the quick look methodology. ${ }^{27}$ The decision reversed the Ninth Circuit's use of the quick look and the Federal Trade Commission's appli-

18. See generally Spencer Weber Waller, Justice Stevens and the Rule of Reason, 62 SMU L. REv. (forthcoming 2009) (emphasizing the leadership of Justice Stevens in establishing a new style of rule of reason analysis).

19. See Cont'l T.V., Inc. v. GTE Sylvania, Inc., 433 U.S. 36, 59 (1977) (applying rule of reason to vertical territorial restriction and calling for analysis of "demonstrable economic effect rather than ... upon formalistic line drawing").

20. See Gen. Leaseways, Inc. v. Nat'l Truck Leasing Ass'n, 744 F.2d 588, 595 (7th Cir. 1984) (using quick look to conclude that defendant's division of markets was per se illegal).

21. Id.

22. See NCAA v. Bd. of Regents of the Univ. of Okla., 468 U.S. 85, 103-04 (1984).

23. Nw. Wholesale Stationers, Inc. v. Pac. Stationery \& Printing Co., 472 U.S. 284, 297 (1985).

24. See Catalano, Inc. v. Target Sales, Inc., 446 U.S. 643, 648-50 (1980).

25. Arizona v. Maricopa County Med. Soc'y, 457 U.S. 332, 348-54 (1982).

26. Cal. Dental Ass'n v. FTC, 526 U.S. 756 (1999).

27. See, e.g., Stephen Calkins, California Dental Association: Not a Quick Look But Not The Full Monty, 67 AnTrTrust L.J. 495, 556 (2000) (concluding that the FTC would avoid using the term "quick look" after California Dental). 
cation of the quick look approach. ${ }^{28}$ In place of the quick look shortcut, the California Dental decision seemingly called for a robust application of the rule of reason and a full evaluation of both anti- and pro-competitive implications of an alleged restraint. ${ }^{29}$ Nonetheless, the California Dental opinion expressly referred to the quick look approach and seemed to treat it as though it were a working methodology that had merely been misapplied by the court of appeals. ${ }^{30}$ California Dental left the quick look approach in limbo-rejected in application but alive in theory. A seemingly straightforward footnote in the 2006 Texaco Inc. v. Dagher ${ }^{31}$ decision described the quick look doctrine with apparent approval, ${ }^{32}$ leaving the approach extant, if not enthusiastically, embraced.

In the past eleven years since California Dental, ambiguity has been the word of the day regarding antitrust methodology. In this period, courts employed the quick look approach sporadically and with mixed results. ${ }^{33}$ Some decisions ignored using a quick look. Commentators called for jettisoning the quick look because of its resemblance to the per se approach and a procedure calling for the defendant to establish pro-competitive justifications. ${ }^{34}$ Nevertheless, the Federal Trade Commission (FTC) employed the quick look in its In re PolyGram Holding, Inc. ${ }^{35}$ opinion and, more recently, in In re North Texas Specialty Physicians. ${ }^{36}$ During this period, however, use of summary judgment in antitrust cases continued to flourish, despite the similar shortcut nature of Federal Rule of Civil Procedure 56. It is uncertain why courts embrace summary judgment in antitrust litigation but at the same time, take care with similar shortcuts such as the quick look.

This Article examines the quick look method and seeks to explain its contemporary relevance and relationship to summary judgment in modern antitrust litigation. I first sketch a brief history of the quick look, then trace the continuing battle to provide even-handed application of summary judgment in all types of civil cases, including antitrust claims, and conclude by examining how conventional summary judgment and the

28. Cal. Dental Ass'n, 526 U.S. at 773-74.

29. Id.

30. See infra text accompanying notes 191-98.

31. 547 U.S. 1 (2006) (permitting two competitors to form a joint-venture selling agent).

32. Id. at 7 n.3 ("To be sure, we have applied the quick look doctrine to business activities that are so plainly anticompetitive that courts need undertake only a cursory examination before imposing antitrust liability.").

33. See, e.g., N. Tex. Specialty Physicians v. FTC, 528 F.3d 346, 362 (5th Cir. 2008) (applying the quick look method "rather than a more searching rule-of-reason inquiry" to affirm the FTC (citing California Dental Ass'n, 526 U.S. at 770-71, for the proposition that quick look analysis applies where a practice has "obvious" anticompetitive effects)).

34. See generally Alan J. Meese, Farewell to the Quick Look: Redefining the Scope and Content of the Rule of Reason, 68 ANTTTRUST L.J. 461 (2000) (attacking quick look as "Populist," overinclusive, and inaccurate). 2005)

35. No. 9298, 2003 WL 21770765 (F.T.C. July 24, 2003), aff'd, 416 F.3d 29 (D.C. Cir.

36. 2005-2 Trade Cas. (CCH) I 75,032 (2005), aff d, 528 F.3d 346 (5th Cir. 2008). 
quick look have the potential to work together as complementary procedures.

\section{A SKETCH OF THE ORIGIN AND NATURE OF THE QUICK LOOK APPROACH}

\section{A. The Quick Look as a Means to Per Se Condemnation}

Although one single, generally accepted definition of the quick look method does not exist, at a visceral level a quick look analysis may be little more than an elegant substitute for per se labeling. Judge Posner's early use of the quick look in his General Leaseways, Inc. v. National Truck Leasing Ass'n decision simply took an abbreviated examination of the alleged horizontal market division to determine if it was per se illegal. ${ }^{37}$ Justice Thomas's footnote in Texaco Inc. v. Dagher casts a similar shadow on the meaning of quick look by describing it as a means to have a "cursory examination" of an alleged restraint to learn if it is "plainly anticompetitive," 38 a buzzword for per se liability. ${ }^{39}$ Use of the quick look to identify per se offenses was similarly embraced in California Dental, which called for an 'abbreviated or 'quick-look' analysis under the rule of reason [when] an observer with even a rudimentary understanding of economics could conclude that the arrangements in question would have an anticompetitive effect on customers and markets." 40 Put differently, the quick look is the opposite of the sort of robust "searching inquiry" associated with the rule of reason. ${ }^{41}$ In Professor Piraino's words, "[t]he quick look is an abbreviated form of analysis similar to the per se rule." 42 Similarly, Professors Gavil, Kovacic, and Baker describe a "quick look to condemn" as aiding a "swift, though not immediate

37. See Gen. Leaseways, Inc. v. Nat'l Truck Leasing Ass'n, 744 F.2d 588, 591 (7th Cir. 1984); see also Vogel v. Am. Soc'y of Appraisers, 744 F.2d 598, 603 (7th Cir. 1984) (Judge Posner asserting that "we should take a quick look to see whether [the alleged restraint prohibiting fees as a percentage of appraisals] has clear anticompetitive consequences and lacks any redeeming competitive virtues").

38. See 547 U.S. 1,7 n.3 (2006).

39. See Nat'l Soc'y of Prof'l Eng'rs v. United States, 435 U.S. 679, 692 (1978); Brunet, supra note 2 , at 8 .

40. Cal. Dental Ass'n v. FTC, 526 U.S. 756, 770 (1999); accord Bogan v. Hodgkins, 166 F.3d 509, 513 (2d Cir. 1999) (referring to quick look as an "abbreviated version of the rule of reason").

41. Gen. Leaseways, 744 F.2d at 595; see also N. Tex. Specialty Physicians v. FTC, 528 F.3d 346, 362 (5th Cir. 2008) (finding the quick look appropriate "only when 'the likelihood of anticompetitive effects is . . obvious,' meaning 'when the great likelihood of anticompetitive effects can easily be ascertained,' and 'after assessing and rejecting [the] logic of proffered procompetitive justifications" (quoting Cal. Dental Ass'n, 526 U.S. at 770-71)); Clarett v. Nat'l Football League, 306 F. Supp. 2d 379, 408-09 (S.D.N.Y. 2004) (terming the NFL draft "the perfect example of a policy that is appropriately analyzed under the 'quick look' standard because its anticompetitive effects are so obvious"), rev'd on other grounds, 369 F.3d 124 (2d Cir. 2004).

42. Thomas A. Piraino, Jr., The Antitrust Analysis of Joint Ventures After the Supreme Court's Dagher Decision, 57 EMORY L.J. 735, $747 \mathrm{n} .88$ (2008) (explaining also that the plaintiff's proof of likely anticompetitive impact shifts the burden of proof to the defendant to show a procompetitive justification); see also Peter C. Carstensen, Using Dagher to Refine the Analysis of Mergers and Joint Ventures in Petroleum Industries and Beyond, 19 
condemnation." 43

There are several problems with limiting the quick look approach to a method merely designed to ferret out per se offenses. First, it is obvious that antitrust lives in the era of the rule of reason. Per se rules have been cut back or confined to their facts and even overruled. The dominant philosophy of antitrust, advanced in Continental T.V., Inc. v. GTE Sylvania calls for economic analysis of every alleged restraint and involves a hands-on, detailed application of economic impact, the opposite of the cursory examination associated with the quick look. ${ }^{44} \mathrm{~A}$ quick look method designed to identify candidates for per se illegality would be a narrow, seldom-used tool. ${ }^{45}$ Professor Meese has criticized the quick look methodology because of its tendency to lead to the use of inaccurate per se labeling. ${ }^{46}$

Second, the sort of quick look method limited to identification of per se offenses is vague and discretionary in nature. Equating the quick look with an inquiry into whether a restraint is "plainly anticompetitive" creates a quick look method close to per se analysis and makes the quick look redundant. ${ }^{47}$ The vague description of the quick look in United States v. Brown University appeared to create a separate type of analysis: not quite per se and not quite rule of reason. ${ }^{48}$ The FTC's PolyGram Holding ${ }^{49}$ decision is illustrative. There, the FTC found the defendants' contract to be "inherently suspect" through the use of a quick look without a structural examination..$^{50}$ This truncated approach earned the ire of critics, who concluded that the quick look was merely an "expanded per se analysis" enabling the FTC to avoid proving market definition or market effect. ${ }^{51}$ While these critiques ring true, such an analysis might find

Loy. Consumer L. Rev. 447, 455 (2007) (surmising the negative reaction of the U.S. business community of equating the per se and quick look approaches to illegality).

43. Andrew I. Gavil et al, Anttrrust Law in Perspective: Cases Concepts, and Problems in Competition Policy 196-201 (2002).

44. See Continental T.V., Inc. v. GTE Sylvania, 433 U.S. 36, 58-59 (1977).

45. See, e.g., Jame Fine Chems., Inc. v. Hi-Tech Pharm. Co., No. 00-3545 (AET), 2007 WL 927976, at*4 (D.N.J. Mar. 27, 2007) (repudiating the quick look method because violations alleged were vertical and required to be assessed under the rule of reason).

46. Alan J. Meese, Farewell to the Quick Look: Redefining the Scope and Content of the Rule of Reason, 68 ANTITRUST L.J. 461, 465 (2000) (urging "[e]limination of the quick look as a separate mode of analysis," resulting in a "more careful delineation of the boundary between" rule of reason and per se analysis); accord In re Echlin Mfg. Co., 105 F.T.C. 410 (1985) (accusing the FTC majority of improperly using the quick look to prove entry barriers leading to a rule of per se legality) (Bailey, Comm'r, dissenting).

47. See supra notes 38-39 and accompanying text.

48. See United States v. Brown Univ., 5 F.3d 658, 669 (3d Cir. 1993) (asserting that the quick look "applies in cases where per se condemnation is inappropriate, but where 'no elaborate industry analysis is required to demonstrate the anticompetitive character' of an inherently suspect restraint") (quoting Nat'l Soc'y of Prof'l Eng'rs v. United States, 435 U.S. 679, 692 (1978)).

49. In re PolyGram Holding, Inc. No. 9298, 2003 WL 21770765 (F.T.C. July 24, 2003); see also PolyGram Holding, Inc. v. FTC, 416 F.3d 29 (D.C. Cir. 2005) (discussing the F.T.C. opinion).

50. In re PolyGram, 2003 WL 21770765, at $\$ 35-40 ;$ PolyGram, 416 F.3d at 32-33.

51. See, e.g., Catherine Verschelden, Is the Quick-Look Antitrust Analysis in PolyGram Holding Inherently Suspect?, 32 J. CORP. L. 447, 459 (2007) (describing the "sus- 
efficiencies associated with an alleged restraint and thereby advance utility by avoiding the heavy cost of a detailed examination of the market.

Third, appellate courts will be fast to overturn findings and conclusions reached too quickly and summarily. Consider the alleged horizontal conspiracy to sell television broadcast rights in Chicago Professional Sports Ltd. Partnership v. NBA. ${ }^{52}$ There, the case went to a trial in a mere seven weeks. ${ }^{53}$ The Seventh Circuit called the court's speedy action "greased lightning," noted that alleging illegal conduct takes "time to develop and more time to test," and railed against "ignorance about the effects of business practices." 54 Similarly, the Third Circuit has overturned lower court use of the quick look in its Brown University decision in order to more fully assess the pro-competitive impact under full rule of reason impact. ${ }^{55}$

\section{B. The Quick Look Rule of Reason: A Means or an End?}

In great contrast, an alternative way of deconstructing the quick look is to think of it as an abbreviated version of a potentially detailed rule of reason approach and to consider the quick look to apply to all antitrust cases, whether likely to be per se or rule of reason in nature. Translated to the firing lines of litigation, this type of quick look approach might well be advanced by a defendant in a pretrial motion rather than being the exclusive tool of the antitrust plaintiff. ${ }^{56}$ Like the rule of reason, this version of the quick look considers pro-competitive and anti-competitive impact. ${ }^{57}$ Indeed, some commentators and courts connect the quick look to the rule of reason in their phraseology by terming this method as the "quick look rule of reason," 58 the "flexible rule of reason," 59 or the "trun-

picion, distrust, and outrage in the antitrust community" as a result of the use of the quick look in the PolyGram Holding decision); see also James A. Keyte \& Neal R. Stoll, Markets? We Don't Need No Stinking Markets! The FTC and Market Definition, 49 ANTITRUST BuLl. 593, 611 (2004) (calling the future of quick look use "unpredictable and murky").

52. 95 F.3d 593 (7th Cir. 1996).

53. Id. at 596.

54. Chi. Prof'l Sports Ltd. v. NBA, 961 F.2d 667, 676 (7th Cir.), cert denied 506 U.S. 954 (1992).

55. United States v. Brown Univ., 5 F.3d 658, 678 (3d Cir. 1993).

56. See, e.g., Blubaugh v. Am. Contract Bridge League, No. IP 01-358-C H/K, 2004 WL 392930, at *1, *17 (S.D. Ind. Feb. 18, 2004) (granting summary judgment for defendants using quick look approach and rejecting plaintiff's boycott theory following his eighteen month suspension).

57. $I d$. at $* 17$.

58. See, e.g., In re Nw. Airlines Corp., 208 F.R.D. 174, 204 (E.D. Mich. 2002) (referring to the trial court applying "a quick look Rule of Reason" to alleged restraint); United States v. Visa U.S.A., Inc., 163 F. Supp. 2d 322, 344 (S.D.N.Y. 2002) (referring to a " "quicklook' rule of reason analysis"); Mark A. Lemley \& Christopher R. Leslie, Categorical Analysis in Antitrust Jurisprudence, 93 Iowa L. Rev. 1207, 1215-16 (2008) (describing a "form of abbreviated or 'quick look' rule of reason"); Max R. Shulman, The Quick Look Rule of Reason: Retreat From Binary Antitrust Analysis, 2 Sedona Conf. J. 89,89 (2001) (noting that "[t]he quick look rule of reason mediates between the per se rule and the full blown rule of reason").

59. See Calkins, supra note 27 , at 529. 
cated" rule of reason. ${ }^{60}$ Regardless of which name is used, this version of quick look holds potential for a more complete style of antitrust methodology, with attention given to the economic impact of an alleged restraint in order to decide whether a full rule of reason trial is necessary. In short, this version of the quick look appears evidentiary in nature and fails to offer a settled middle ground between the traditional per se and rule of reason categories. Instead, this justification of the quick look emphasizes an attempt to trim the potentially overly complex rule of reason in an era of minimal use of per se rules. ${ }^{61}$

This more balanced version of the quick look methodology is evidenced in its early use in briefs filed by government lawyers. The 1981 amicus curiae brief of the United States in Maricopa County Medical Society describes the need for an "initial inquiry-which may be denominated either a 'quick look' to determine the applicability of the per se rule or a limited rule of reason inquiry."62

Of course, the quick look methodology needs to save resources and facilitate accurate decisions to be justifiable. It is possible to think of the quick look procedure as a time-saving presumption of anti-competitive effect. Once the plaintiff proves an offense that is facially anti-competitive, the burden to show a positive impact on competition in the form of lower prices or increased output shifts to the defending party. ${ }^{63}$ Presumably, the defending party's failure to show evidence of pro-competitive impact will lead to a finding of illegality, ${ }^{64}$ a process that has but one additional layer of proof as compared to a close to automatic per se classification.

Several quick look decisions conserve resources by omitting rule of reason style proof of market power. For example, in Law v. NCAA, the district court applied "the quick look standard [where] adverse effects on competition [were] apparent" and observed that "the court [did] not require proof of market power, and instead move[d] directly to an analysis of the defendant's proffered competitive justifications."65 Professor Hovenkamp argues that a quick look at market power is justifiable in

60. See, e.g., In re Echlin Mfg. Co., 105 F.T.C. 410 (1985) (calling in its advisory opinion, 1985 WL 668902 (FTC Apr. 19, 1985) for a "truncated, quick-look, or limited rule of reason analysis").

61. See GAvIL ET AL., supra note 43, at 196-201 (describing the "quick look to exonerate" after positing a "quick look to condemn").

62. Brief for the United States as Amicus Curiae at 8, Arizona v. Maricopa County Med. Soc'y, 457 U.S. 332 (1982) (No. 80-419), 1981 WL 390409, at *8.

63. See United States v. Brown Univ., 5 F.3d 548, 768 (3d Cir. 1993) (reversing for full rule of reason treatment a district court ruling using a quick look and calling for a burden shift to defendants to prove pro-competitive impact); 11 Herbert HovenKamP, ANTItrust law: An Analysis of Antitrust Principles and Their Application 355 (2d ed. 2005) (describing a quick look method involving burden shifting to the defendant, who must establish competitive justifications that support a restraint). Note that this is a form of substantive burden shifting, not to be confused with procedural burden shifting mandated by the Celotex Corp. v. Catrett, 477 U.S. 317 (1986), decision.

64. HovenKAMP, supra note 63 , at 356.

65. Law v. NCAA, 902 F. Supp. 1394, 1405 (D. Kan. 1995). 
cases where a per se rule is overly broad but a rule of reason inquiry is unnecessary, and advances the "pay for delay" In re Cardizem CD Antitrust Litigation ${ }^{66}$ case as an example. ${ }^{67}$ The FTC's and Department of Justice's 2000 Antitrust Guidelines for Collaborations Among Competitors takes a similar approach by calling for a quick look at market power and the nature of the alleged restraint before undertaking a more detailed and elaborate rule of reason analysis. 68

Some decisions appear willing to use a quick look when confronted with an alleged restraint that appears to be novel or unfamiliar in previous antitrust litigation. ${ }^{69}$ Although this course of action seems rational, there is reason to be skeptical of what appear to be clichés restricting a streamlined analysis to "considerable past experience."70 Justice Stevens's warning against "rejustif[ying]" the per se rule on an industry by industry basis seems well-reasoned. ${ }^{71}$ Professor Hovenkamp logically argues that a truly new product or service must be involved to trigger a more thorough analysis and suggests that the alleged idiosyncrasy must be at the heart of the restraint to invoke greater scrutiny. ${ }^{72}$

The cautionary views regarding the quick look approach of Stephen Calkins merit particular attention. In the definitive examination of the quick look, Professor Calkins sets out a skeptical picture of the quick look's future. He terms California Dental a "setback" for the "quick look' antitrust movement," 73 correctly warns that the Court linked use of the quick look to "premature burden shifting," 74 and interprets Justice Souter's opinion as a "setback for market power screens." 75 After all, the FTC failed to define a precise market, pinpoint barriers to entry, or call an expert. ${ }^{76}$ The refusal to endorse the quick look approach in California Dental led Calkins to predict that he "[could not] imagine that the FTC [would] soon employ the term in an adjudicated opinion" and to caution against reliance on set formulas. ${ }^{77}$

66. 332 F.3d 896 (6th Cir. 2003).

67. 12 HovenKAMP, supra note 63 , at 328-29.

68. FTC \& Dep't OF Justice, AntTtrust Guidelines for Collaborations AMONG COMPETITORS 4 (2000), available at http://www.ftc.gov/05/2000/04/ ftcdojguidelines.pdf.

69. See, e.g., United States v. Topco Assocs., 405 U.S. 596, 607-08 (1972) (declaring a willingness to apply per se classification when courts have "considerable experience" with the business practice at issue).

70. See Brunet, supra note 2, at 3 (criticizing use of clichés in per se/rule of reason analysis).

71. Id. at 7 (citing Arizona v. Maricopa County Med. Soc'y, 457 U.S. 332, 351 (1982)).

72. See Hovenkamp, supra note 63, at 306 (noting that "[t]his condition has often been found to be met in the cases involving the NCAA or a professional sports league as defendants").

73. Calkins, supra note 27, at 531; accord, 12 HovENKAMP, supra note 63 , at 117 (asserting that California Dental "narrows the range of horizontal actions that can [be] subjected to a "quick look"').

74. Calkins, supra note 27 , at 532 .

75. Id. at $496-97$.

76. See id. at 535 .

77. Id. at 556-57. 
Professors Lemley and Leslie set forth an instrumental description of the quick look approach that seems logical and useful. ${ }^{78}$ In order to avoid mistakes in characterizing an alleged restraint as either per se or subject to a full rule of reason, they envision the quick look as "an effort to characterize disputed conduct" in which the defendant is offered a pretrial opportunity to show pro-competitive justifications for the allegedly illegal conduct. ${ }^{79}$ Professors Lemley and Leslie helpfully perceive the quick look as a sort of evidence rule permitting pretrial classification decisions without a full economic analysis. Viewed in this light, they suggest, California Dental merely avoided approving a quick look that had become, in the Court's eyes, a separate (and confusing) third category of analysis or an abbreviated version of the rule of reason.

\section{THE ROLE OF SUMMARY JUDGMENT IN ANTITRUST LITIGATION}

Before the phrase "quick look" ever graced a decision or brief, antitrust opinions used summary judgment and the per se concept to streamline analysis and facilitate categorization. This section explores summary judgment's role as a shortcut tool in antitrust litigation.

\section{A. A Theory of a Transsubstantive Rule 56}

The original 1938 version of the Federal Rules of Civil Procedure was designed to be transsubstantive, a system of procedural rules "generalized across substantive lines." 80

This philosophy theorized that each procedural rule should be applied in a uniform, general fashion, without regard to the cause of action alleged. The goal of a transsubstantive system was to develop a one-stop, easy-to-identify rules system and to place the courts in the enviable posture of avoiding "interest group politics" 81 when construing the rules.

As developed by Justice Charles Clark, then the reporter of the advisory committee in charge of drafting rules, ${ }^{82}$ the rules system put into place in 1938 sought to use one set of norms for all types of civil cases. Justice Clark strongly opposed allowing special rules for particular cases and made the notion of uniformity a preeminent ethos underlying the

78. See Lemley \& Leslie, supra note 58, at 1215.

79. Id.

80. Cover, supra note 13, at 718; accord, Paul D. Carrington, Making Rules to Dispose of Manifestly Unfounded Assertions: An Exorcism of the Bogy of Non-Trans-Substantive Rules of Civil Procedure, 137 U. PA. L. Rev. 2067, 2080-81 (1989) [hereinafter Carrington, Making Rides] (describing "centuries of adverse experience with substance-specific procedures").

81. See Paul D. Carrington, "Substance" and "Procedure" in the Rules Enabling Act, 1989 Duke L. J. 281, 303-04; Carrington, Making Rides, supra note 80, at 2070 (referring to and arguing for a "principle of generalism" underlying the Federal Rules of Civil Procedure).

82. Order Appointing Committee to Draft Unified System of Equity and Law Rules, 295 U.S. 774 (1935); see also Michael E. Smith, Judge Charles E. Clark and the Federal Rules of Civil Procedure, 85 YALE L.J. 914, 915 (1976). 
rules. ${ }^{83}$ This reform, which was also supported strongly by Chief Justice Taft, ${ }^{84}$ won the day with the Supreme Court's approval of then Judge Clark's draft set of rules in 1938. Included in the new rules was a transsubstantive Rule 56, designed to apply the same way in any type of case.

Following his appointment to the Second Circuit Court of Appeals, Judge Clark fought his fellow Circuit judges in pursuit of an even-handed application of summary judgment and motions to dismiss that ignored the specific variety of claim presented. In Arnstein v. Porter, Clark's dissent lamented the "dislike of the summary-judgment rule" that was "difficult to appraise or understand." 85 Judge Clark stressed that "the clear-cut provisions of [Federal Rule of Civil Procedure] 56 conspicuously do not contain either a restriction on the kinds of actions to which it is applicable" and asserted that summary judgment was "an integral and useful part of the procedural system envisaged by the rules." 86 Judge Clark's opinion reversing a motion to dismiss in Nagler v. Admiral Corp, an antitrust conspiracy claim, is noteworthy in its defense of a transsubstantive vision of adjudication. ${ }^{87}$ Judge Clark insisted that antitrust cases be measured using notice pleading norms identical to other causes of action by urging "that the federal rules contain no special exemptions for antitrust cases." 88 Historical research reveals Judge Clark's "satisfaction that [the Nagler] decision had at least temporarily halted the campaign for special pleading in antitrust cases." 89 Articles written by Judge Clark while he was on the bench praised the universal application of Rule 56 and criticized rules and decisions that confined summary judgment to case-specific, designated categories. ${ }^{90}$

\section{B. The Practical Meaning of Transsubstantive Antitrust Summary Judgment: No Special Latitude Given to The Antitrust Nonmovant}

\section{The Inconsistent Poller Years: 1962-1985}

Despite the Justice Clark's mission to adopt a transsubstantive Rule 56, the Supreme Court dealt antitrust summary judgment a deafening blow in its 1962 Poller v. CBS, Inc. decision. ${ }^{91}$ The plaintiff, owner of a UHF television station in Milwaukee, alleged that CBS had conspired to rid the

83. See, e.g., Charles E. Clark \& James W. Moore, A New Federal Civil Procedure, 44 YALE L.J. 387, 387-89 (1935).

84. See William Howard Taft, Three Needed Steps of Progress, 8 A.B.A. J. 34, 35 (1922) (advocating a simplified and uniform procedure to be used in all types of cases).

85. Arnstein v. Porter, 154 F.2d 464, 479 (2d Cir. 1946) (Clark, J., dissenting).

86. Id; ; see also MacDonald v. Du Maurier, 144 F.2d 696, 702 (2d Cir. 1944) (asserting that summary judgment is "available for all-not a selected few-civil actions") (Clark, J., dissenting).

87. See Nagler v. Admiral Corp., 248 F.2d 319, 321, 328 (2d Cir. 1957).

88. Id. at 323 .

89. Smith, supra note 82, at 925 (citing Clark letter of Oct. 14, 1957 to Julius Abeson).

90. See Charles E. Clark, The Summary Judgment, 36 MinN. L. Rev. 567,569 (1952).

91. See Poller v. CBS, Inc., 368 U.S. 464 (1962). 
market of UHF television by purchasing its own UHF station, canceling Poller's network affiliation, and "forcing" Poller to sell his station to it. ${ }^{92}$ Reasoning that CBS had the right to purchase Poller's station and relying on four CBS affidavits, each showing CBS's lack of motive, the district court granted summary judgment. ${ }^{93}$ The court of appeals affirmed, asserting that CBS had a contractual right to terminate the UHF competitor station and, accordingly, could not conspire to eliminate a competitor. ${ }^{94}$

In an opinion that placed a heavy burden of summary judgment production upon the moving party, the Supreme Court's reversal stressed that CBS had failed to produce "conclusive evidence supporting [its] theory."95 While the Poller decision is flatly inconsistent with the burdenshifting dynamic of Celotex Corp. $v$. Catrett ${ }^{96}$ it is the following passage of Justice Clark's opinion that heavily influenced the lower federal courts to be skeptical of granting summary judgment in antitrust litigation:

[S] ummary procedures should be used sparingly in complex antitrust litigation where motive and intent play leading roles, the proof is largely in the hands of the alleged conspirators, and hostile witnesses thicken the plot. It is only when the witnesses are present and subject to cross-examination that their credibility and the weight to be given their testimony can be appraised. ${ }^{97}$

Despite the transsubstantive dissent of Justice Harlan, ${ }^{98}$ numerous denials of summary judgment in antitrust cases appear to be based on this language. ${ }^{99}$

Poller's cautionary and unnecessary dictum appears inconsistent with the factual record presented in the case. The Rule 56 motion should and could have been denied using a conventional summary judgment analysis. ${ }^{100}$ The Court found damaging admissions in the moving party's affidavits and explained that these admissions created factual inferences for

92. Id. at $465-66$.

93. Id. at 468; Poller v. CBS, Inc., 174 F. Supp. 802, 805 (D.D.C. 1959).

94. Poller v. CBS, Inc., 284 F. 2d 599, 603 (D.C. Cir. 1960).

95. Poller, 368 U.S. at 473.

96. See Celotex Corp. v. Catrett, 477 U.S. 317, 323 (1986) (creating a light burden of production for the moving party who lacks the burden of proof at trial).

97. Poller, 368 U.S. at 473.

98. Harlan's dissent contended that "there is good reason for giving the summary judgment rule its full legitimate sweep in [the antitrust] field." Poller, 368 U.S. at 478 (Harlan, J., dissenting).

99. See, e.g., Norfolk Monument Co. v. Woodlawn Mem'l Gardens, Inc., 394 U.S. 700 , 704 (1969) (reversing an award of summary judgment by relying on Poller); Forsyth v. Humana, Inc., 114 F.3d 1467, 1478 (9th Cir. 1997) (reversing summary judgment, and asserting that "[c]omplex antitrust cases ... invariably involve complicated questions of causation and damages"); Indus. Bldg. Materials, Inc. v. Interchemical Corp., 437 F.2d 1336, 1345 (9th Cir. 1970) (relying on Poller and finding insufficient information to use summary judgment); Am. Mfrs. Mut. Ins. Co. v. Am. Broad. Paramount Theaters, Inc., 388 F.2d 272, 279-80 (2d Cir. 1967) (reversing summary judgment and, citing Poller, concluding that "we have been forewarned that the use of summary judgment in complex antitrust litigation must be closely scrutinized"),

100. See Recommendations of the Am. Coll. Of Trial Lawyers on Major Issues Affecting Complex Litig., 90 F.R.D. 207, 227 (1981). 
trial. ${ }^{101}$ Serious credibility questions remained and would have prevented summary judgment, even in today's burden-shifting paradigm.

In the years following the Poller decision, several major cases treated the dictum as either a misstatement or a non-event. In White Motor Co. $v$. United States, the majority asserted that "[s]ummary judgments have a place in the antitrust field, as elsewhere," but qualified this truism by suggesting that "where ... the gist of the case turns on documentary evidence, the rule at times can be divined without a trial."102 The First National Bank of Arizona v. Cities Service Co. decision limited the scope of Poller by observing that summary judgment should not be "read out of antitrust cases" and differentiated Poller as a holding where "it was plausible for the plaintiff to argue that CBS had embarked on a plan to drive him out of business." 103

In contrast, Norfolk Monument Co. v. Woodlawn Memorial Gardens, Inc. relied on Poller in reversing summary judgment that had been affirmed by the court of appeals. ${ }^{104}$ Reasoning that "the alleged conspiracy had not been conclusively disproved by pretrial discovery," the Court identified inferences regarding alleged parallel conduct of the defendants and disputed business justifications. ${ }^{105}$ Norfolk Monument allocated a heavy summary judgment burden of production to the moving party to "conclusively disprove[ ]" the allegations of the non-movant plaintiff. ${ }^{106}$ Norfolk Monument appears flatly inconsistent with Cities Service and carried a Poller-like message that lower courts should be reluctant to grant summary judgment in antitrust conspiracy litigation. ${ }^{107}$

Even before the rejuvenation of summary judgment stemming from the 1986 trilogy, there were signals from the Supreme Court that antitrust summary judgment was not forbidden. The Court's per curium opinion in Catalano, Inc. v. Target Sales, Inc. reversed a Ninth Circuit opinion ${ }^{108}$ affirming the district court's pretrial order that rejected the alleged re-

101. See id.

102. White Motor Co. v. United States, 372 U.S. 253, 259 (1963).

103. First Nat'l Bank of Ariz. v. Cities Serv. Co, 391 U.S. 253, 285, 289 (1968).

104. See Norfolk Monument Co., 394 U.S. at 704.

105. Id. at 703-04.

106. C. Paul Rogers III, Summary Judgments in Antitrust Conspiracy Litigation, 10 LoY. U. CHI. L.J. 667, 673 (1979).

107. For lower court decisions demonstrating wariness toward antitrust summary judgment relying on Poller, see, for example, Bouldis v. U.S. Suzuki Motor Corp., 771 F.2d 1319, 1324 (6th Cir. 1983) (terming the rule in Poller "well-established"), Industrial Building Materials, Inc. v. Interchemical Corp., 437 F.2d 1336, 1345 (9th Cir. 1970) (asserting that "[j]ust as the Supreme Court had insufficient information in Poller to pass on the question of monopolization, so we too are limited here by the fact that there was no trial at which these issues could be factually developed ...."), Welchlin v. Tenet Healthcare Corp., $366 \mathrm{~F}$. Supp. 2d 338, 351-52 (D.S.C. 2005) (emphasizing the importance of trying complex antitrust cases before a jury because the court is unable to weigh evidence in ruling on summary judgment), Industrial Burner Systems, Inc. v. Maxon Corp., 275 F. Supp. 2d 878, 882 (E.D. Mich. 2003) (noting that "summary judgment should be used sparingly in complex antitrust litigation").

108. Catalano, Inc. v. Target Sales, Inc., 446 U.S. 643, 650 (1980). 
straint as per se illegal. ${ }^{109}$ The Supreme Court showed the confidence to use the per se label to a conspiracy to eliminate short-term credit to liquor retailers and did so on a pretrial record lacking a plenary trial. ${ }^{110}$

A short two years later, the Court reiterated the viability of antitrust summary judgment in Arizona v. Maricopa County Medical Society. ${ }^{111}$ In an opinion relying on substantive antitrust doctrine to hold per se illegal physician-set maximum fees and eschewing any elaboration relating to summary judgment, the Court reversed the Ninth Circuit's order affirming the trial court's denial of summary judgment. ${ }^{112}$ It is noteworthy that the briefs filed by the United States called for the Court to take a "quick look" of the alleged restraint to determine anti-competitive impact. ${ }^{113}$ While the opinion of the Court did not use the quick look rubric, Maricopa County endorsed the utility of antitrust summary judgment by its overturning of the district court's refusal to grant the motion and clearly signaled its willingness to evaluate efficiency arguments on a pretrial summary judgment record. ${ }^{114}$

The Court continued its de facto pro-summary judgment attitude in Northwest Wholesale Stationers, Inc. v. Pacific Stationery \& Printing Co. ${ }^{115}$ By overturning the court of appeals's reversal of summary judgment, the Supreme Court again displayed a policy that endorsed the use of Rule 56 to decide antitrust litigation. ${ }^{116}$ Northwest Wholesale Stationers also ignored the anti-summary judgment language of Poller, thereby placing the 1962 dictum in a precarious status.

Northwest Wholesale Stationers fashioned a proof requirement for plaintiffs seeking a per se rule in boycott cases by mandating the presentation of a "threshold case" that the "challenged activity falls into a category likely to have predominantly anticompetitive effects."117 This procedural point, made in a case overturning the reversal of summary judgment, conveys the impression that Rule 56 can be used to assess anticompetitive impact and can do so in a pretrial fashion.

Although the Court failed to define what it meant by a "threshold case" of anti-competitive effects, it clearly signaled that this inquiry was pretrial in nature. The procedural context of the litigation ${ }^{118}$ involved

109. Catalano, Inc. v. Target Sales, Inc. 605 F.2d 1097, 1101-02 (9th Cir. 1979).

110. See Catalano, Inc., 446 U.S. at 643, 647-48.

111. See Arizona v. Maricopa County Med. Soc'y, 457 U.S. 332, $335-36$ (1982).

112. See id. at $347-48,351,357$.

113. See, e.g., Brief for the United States as Amicus Curiae at 15, 34, 40, Arizona v. Maricopa County Med. Soc'y, 457 U.S. 332 (1982) (No. 80-419), 1981 WL 390409; see also Brief for the United States as Amicus Curiae in Support of Affirmance at 8-9, NCAA v. Bd. of Regents of the Univ. of Okla., 468 U.S. 85 (1984) (No. 83-271), 184 U.S.S. Ct. Briefs LEXIS 60 (urging use of quick look methodology).

114. See Maricopa County, 457 U.S. at 335-36.

115. 472 U.S. 284 (1985).

116. Id. at 298.

117. Id. at 298. The Court's required showing mandated proof that the alleged restraint "cut off access to a supply, facility, or market necessary to enable the boycotted firm to compete." Id. at 294.

118. See id. at $286,288$. 
cross-motions for summary judgment and a trial court order granting the defendant's motion for summary judgment, followed by a Ninth Circuit reversal based upon a now-discarded interpretation of Silver v. New York Stock Exchange ${ }^{119}$ that called for a hearing in advance of an expulsion from a joint venture. ${ }^{120}$ It seems noteworthy that Justice Brennan's opinion referred to the district judge as following the "correct path of analysis." 121 Presumably, the Court was referring to using summary judgment to assess alleged anti-competitive impact. No alternative explanation for such a "threshold case" exists. ${ }^{122}$

\section{Matsushita and the Demise of the Poller Dictum}

Matsushita Electric Industrial Co. v. Zenith Radio Corp. ${ }^{123}$ is a landmark summary judgment case as well as an important section 2 Sherman Act substantive holding. As a matter of antitrust substance, Matsushita held that predation claims must show that recoupment is plausible. ${ }^{124}$ As a matter of procedure, Matsushita displayed a pro-Rule 56 attitude by overturning a Third Circuit decision that had reversed the district judge's grant of summary judgment. ${ }^{125}$ The Court completely ignored its earlier Poller decision in holding that an alleged antitrust conspiracy against a group of twenty-one Japanese television manufacturers could be decided by summary judgment. ${ }^{126}$ In so doing, Matsushita exorcized the homily that antitrust conspiracy claims were questionable candidates for summary judgment.

The sheer size of the Matsushita litigation bears significance. This was the paradigm big, complex antitrust case. The summary judgment record was indeed voluminous, supposedly relying upon a forty volume appendix filed by the parties at trial. ${ }^{127}$ A court skeptical of summary judgment might have easily rested on the old song that complex cases, especially those involving conspiracy allegations, were poor candidates for Rule 56 usage. Instead, the Court's reinstatement of the trial court's summary judgment signaled that summary judgment had utility in big cases.

Prior to Matsushita, some decisions denied motions for summary judgment using an old, now-rejected, "slightest doubt" approach. ${ }^{128}$ The theory underlying this standard for summary judgment was that the motion

119. 373 U.S. 341 (1963).

120. See Denver Rockets v. All-Pro Mgmt., Inc., 325 F. Supp. 1049, 1065 (C.D. Cal. 1971) (calling for procedural safeguards to avoid per se liability in a boycott context).

121. Nw. Wholesale Stationers, Inc., 472 U.S. at 297.

122. See id. at 298.

123. 475 U.S. $574(1986)$.

124. See id. at 588-89, 592.

125. See id. at 596-98.

126. See id. at 574.

127. See id. at 577.

128. See, e.g., Arnstein v. Porter, 154 F.2d 464, 468, 471, 475 (2d Cir. 1946) (suggesting that a motion for summary judgment should be denied if the "slightest doubt" regarding the existence of disputed facts exists and reversing a district court grant of summary judgment in a copyright infringement claim against Cole Porter); Doehler Metal Furniture Co. v. United States, 149 F.2d 130, 135 (2d Cir. 1945) (stating that "trial judges should exercise 
must be denied if the slightest doubt existed as to disputed facts. This theory, historically accepted but now clearly rejected, ${ }^{129}$ was opposed strongly by Judge Charles Clark and was attacked more recently by Judge Jack Weinstein. ${ }^{130}$ Both questioned whether summary judgments could ever be granted if courts took the slightest doubt standard literally. ${ }^{131}$

Matsushita seemingly jettisoned the slightest doubt approach and, by so doing, created a modern and dynamic summary judgment mechanism. In an important passage, the Matsushita Court asserted that the nonmovant, Zenith, must demonstrate disputed issues by "more than simply show[ing] that there is some metaphysical doubt as to the material facts." 132 Although the word "metaphysical" might seem cryptic, it seems clear that the nonmmovant must come forth with evidence showing more than mere doubt. Examination of the authorities cited by the majority opinion confirms the intent to repudiate the slightest doubt standard. ${ }^{133}$

Matsushita is also an important summary judgment holding in other respects. It clarified that the standard for granting summary judgments was identical to directed verdict. ${ }^{134}$ It also taught that the old summary judgment cliché of weighing inferences in favor of the nonmovant was conditional by stating that "antitrust law limits the range of permissible inferences from ambiguous evidence in a $\S 1$ case."135 As applied by the Matsushita majority, this means that the district judge should not weigh inferences in favor of the nonmoving party because the plaintiff's assertions made "no economic sense" 136 and the defendants "had no rational ... motive to conspire." 137

It is important to emphasize that the Matsushita decision failed to articulate a new rule mandating a showing of "plausible" proof by the non-

great care in granting motions for summary judgment" and that "[a] litigant has a right to a trial where there is the slightest doubt as to the facts ....").

129. See Edward J. Brunet \& Martin H. Redish, Summary Judgment: Federal LAW AND PRACTICE 130-31 (3d ed. 2006) (collecting commentary and cases ignoring or rejecting slightest doubt test). Trial by inspection, the common law analog to modern summary judgment, could only be granted where a visual observation by the judge showed that a disputed fact was "obvious" or not in doubt. See Edward Brunet, Summary Judg. ment is Constitutional, 93 Iowa L. REv. 1625, 1630-31 (2008).

130. See Chubbs v. City of N.Y., 324 F. Supp. 1183, 1189 (E.D.N.Y. 1971) (asserting that the slightest doubt rule, if "taken seriously, means that summary judgment is almost never to be used-a pity in this critical time of overstrained legal resources"); Charles E. Clark, Special Problems in Drafting and Interpreting Procedural Codes and Rules, 3 VAND. L. REv. 493, 504 (1950) (stating that if the slightest doubt standard is used as stated "there can hardly be a summary judgment ever").

131. See supra note 130 .

132. See Matsushita Elec. Indus. Co. v. Zenith Radio Corp., 475 U.S. 574, 586 (1986).

133. See id. at 587 (citing First National Bank of Arizona v. Cities Service Co., 391 U.S. 253,289 (1986), as a case where the economic evidence proved a lack of motive to join the alleged conspiracy).

134. Id. at 588 (stating that the same proof burden applies " $[\mathrm{t}] \mathrm{o}$ survive a motion for summary judgment or for a directed verdict").

135. Id.

136. Id. at 587.

137. Id. at 596-97; see also id. at 592-93 (noting that to recoup loses suffered during the lengthy two decade conspiracy period, defendants "would most likely have to sustain their cartel for years simply to break even"). 
movant plaintiff. True, the majority uses the word "implausible" or its opposite, "plausible," a whopping eleven times ${ }^{138}$ and, by so doing, gives an impression that plausibility may be the real test or standard for summary judgment. ${ }^{139}$ This reading of the term "plausible," first used in the 1968 Cities Service decision ${ }^{140}$ and sometimes found in post-Matsushita decisions, ${ }^{141}$ needs to be rejected. First, the decision and its companion, Anderson v. Liberty Lobby, Inc., 142 together forge a new directed verdict standard that asks simply whether the proof could lead to a jury verdict in favor of the nonmovant. Second, judicial usage of a plausibility rule would involve the court in overt weighing of the evidence, a possible violation of summary judgment mechanics and the Seventh Amendment. The repeated use of the term "plausible" 143 must relate to substantive antitrust law and the fact that it was quite unbelievable (or implausible) that the plaintiff's proof required the more than twenty defendants to sell at low prices for twenty-five years and never reach the recoupment state of a predation case. As used in Matsushita, the word "plausible" has a substantive meaning. The Court allocated the plaintiff a similar task to demonstrate plausible proof at the pleading stage in Bell Atlantic Corp. v. Twombly, ${ }^{144}$ a procedural twist that smacks of summary judgment and only makes sense if characterized as a matter of substantive anti-trust law. ${ }^{145}$

\section{A Rule 56-Friendly Reading of Kodak Co.}

It would be a mistake to view Eastman Kodak Co. v. Image Technical Services, Inc. ${ }^{146}$ a decision that affirmed a court of appeals holding which overturned a motion for summary judgment in favor of the defendant Kodak, as a major change of Rule 56 policy. Read prudently, the Kodak

138. Id. at $583,587,591,593-97$.

139. Id. at 587 (stating that "if the factual context renders [plaintiffs'] claim implausible-if the claim is one that simply makes no economic sense-[plaintiffs] must come forward with more persuasive evidence to support their claim than would otherwise be necessary").

140. See First Nat'l Bank of Ariz. v. Cities Serv. Co., 391 U.S. 253, 285 (1968) (referring to Poller as a decision where it "was plausible for the plaintiff to argue that CBS had embarked on a plan to drive him out of business" and, in contrast, asserting that it was "much more plausible to believe that [defendant-movant] Cities' interests coincided" with the plaintiff's).

141. See, e.g., Blue Ridge Ins. Co. v. Stanewich, 142 F.3d 1145, 1147 (9th Cir. 1998) (inquiring whether the plaintiff's proof is implausible in a contractual dispute); Wallace v. SMC Pneumatics, Inc., 103 F.3d 1394, 1400 (7th Cir. 1997) (using plausibility as standard in a civil rights case).

142. 477 U.S. 242 (1986).

143. See supra note 138 and accompanying text.

144. $127 \mathrm{~S}$. Ct. $1955,1964-65$ (2007) (requiring the plaintiff to plead a plausible antitrust conspiracy case in order to survive a Rule 12(b)(6) motion).

145. See generally Richard A. Epstein, Bell Atlantic v. Twombly: How Motions to Dismiss Become (Disguised) Summary Judgment Motions, 25 W AsH U. J.L. \& PoL'Y 61 (2007) (analyzing Twombly as a summary judgment holding rather than a motion to dismiss); A. Benjamin Spencer, Plausibility Pleading, 49 B.C. L. REv. 431 (2008) (detailing the nature of "plausibility pleading" under Twombly).

146. 504 U.S. 451 (1992). 
decision is merely saying that the claim of the eighteen plaintiffs, competitors of Kodak in servicing Kodak copiers, did make economic sense, ${ }^{147}$ particularly in view of the timing of the summary judgment grant. After all, District Judge Schwarzer granted summary judgment before much discovery had been conducted. ${ }^{148}$

Kodak was a very different case than Matsushita and fails to represent a retreat from Matsushita. The defendant Kodak was charged with restricting supply to the plaintiff group of repair competitors ${ }^{149}$ rather than the low prices alleged to have been set by a group of co-conspirators in Matsushita. Justice Blackmun's Kodak opinion found the theory of the nonmoving party plaintiffs attractive, "exactly the harm that antitrust laws aim to prevent." $150 \mathrm{He}$ interpreted Matsushita as only demanding "that the nonmoving party's inferences be reasonable in order to reach the jury."151 This assertion is entirely logical and prudent as an articulation of summary judgment; not every inference can be reasonable, or alternatively, will be economically senseless. Because the plaintiffs' claim cast a supporting inference, the defendant movant was required to show the nonexistence of a critical element of the case-market power. ${ }^{152}$

Commentary and case law regarding the Kodak decision largely support this view. To be sure, Professor Calkins did stress that "Matsushita emboldened courts to address the merits at early stages; Kodak cautions against excessive enthusiasm." 153 In contrast, Professor Weber observed that Kodak merely said that "when it comes to summary judgment, antitrust cases should be treated like all other cases."154 Alan Siberman voiced a similar conclusion when he correctly asserted that "Kodak did not state any new principle of law." 155 This view of Kodak was taken by the Third Circuit when it described Matsushita, while citing Kodak, as a decision that "did not invent a new requirement for an antitrust plaintiff to meet, but merely articulated an established one, i.e., the inferences drown from the proffered evidence must be reasonable."156 Similarly,

147. Id. at $477-78$.

148. See id. at 456.

149. See id. at $458-59$.

150. Id. at 478 .

151. Id. at 468 .

152. Id. at 464 .

153. Stephen Calkins, Supreme Court Antitrust 1991-92: The Revenge of the Amici, 61 AnTitrust L.J. 269, 298 (1993); see also Gordon B. Spivak \& Carolyn T. Ellis, Kodak: Enlightened Antitrust Analysis and Traditional Tying Law, 62 ANTITrust L.J. 203, 207 (1993) (stating that a "likely result of the Kodak decision will be a rebalancing of the requirements for summary judgment in antitrust cases").

154. Mark Weber, Summary Judgment After Kodak, 7 ANTITrust 10 (1992) (asserting that the Kodak decision "sends a clear message ... when it comes to summary judgment, antitrust cases should be treated like all other cases").

155. Alan H. Siberman, If Kodak is Merely "a Summary Judgment Case," Why Don't Antitrust Lawyers Want to Treat It That Way?, C137 A.L.I.-A.B.A. 81, 84 (1995).

156. Petruzzi's IGA Supermarkets, Inc. v. Darling-Delaware Co., 998 F.2d 1224, 1231 (3d Cir. 1993); see also Big Apple BMW, Inc. v. BMW of N. Am., Inc., 974 F.2d 1358, 1363 (3d Cir. 1992) (noting that the nonmovant's burden in an antitrust case is no different than in other kinds of cases). 
the Ninth Circuit echoed this reading of the Kodak decision in Rebel Oil Co. v. Atlantic Richfield Co. ${ }^{157}$ when it affirmed summary judgment for a defendant charged with predatory pricing because the plaintiff's expert's conclusions were "economically unreasonable." 158

\section{Antitrust Summary Judgment is Alive, Diverse, and Working}

Antitrust summary judgment is popular. The filing of summary judgment motions in antitrust litigation appears to exceed the mean filing rate for all summary judgment motions. Professor Hovenkamp recently referred to the courts "developing a remarkably expansive doctrine of 'summary judgment." "159 Courts employ Rule 56 to dispose of a variety of antitrust issues and sometimes use it to resolve an entire case. There appears to be little empirical evidence of misuse of antitrust summary judgment. Antitrust policy requires an early means to test the merits in antitrust litigation to interject substantive reality into a context where there are "powerful incentives to offer claims or defenses of little merit."160

A brief look at statistics compiled by the Federal Judicial Center (FJC) for fiscal year 2006 yields interesting data and confirms the utility of summary judgment motions in antitrust cases. ${ }^{161}$ During this period, about 400 (397 to be exact) cases with antitrust claims were terminated. ${ }^{162}$ In this set of cases, summary judgment motions were made in 103 cases, or, put differently, 26 summary judgment motions were filed per every 100 cases that were terminated. ${ }^{163}$ This $26 \%$ figure compares to a substantially lower rate of filing in all cases-a rate of $17 \%$ for the filing of summary judgment in all types of civil cases. ${ }^{164}$

157. 146 F.3d 1088 (9th Cir. 1998).

158. See id. at 1095 (citing Kodak, 504 U.S. at 468-69); accord, Amerinet, Inc. v. Xerox Corp., 972 F.2d 1483, 1490 (8th Cir. 1992) (stating that "[i]n complex antitrust cases, no different or heightened standard for the grant of summary judgment applies" (citing Kodak, 504 U.S. at 451; Matsushita Elec. Indus. Co. v. Zenith Radio Corp., 475 U.S. 474 (1986)).

159. Herbert Hovenkamp, The Antitrust Enterprise: Principle and ExecuTION 4 (2005).

160. AREEDA ET AL., supra note 1, at 79.

161. See generally Memorandum from Joe Cecil \& George Cort, Fed. Judicial Ctr., to Hon. Michael Baylson, Estimates of Summary Judgment Activity in Fiscal Year 2006 (Apr. 12, 2007) (revised June 15, 2007), available at http://www.fjc.gov/public/pdf.nsf/lookup/ sujufy06.pdf/\$file/sujufy06.pdf.

162. Id. at 7 .

163. Id.

164. Id. at 1 . While this $17 \%$ number may appear surprisingly small to some readers, there is evidence that the number has grown since 1975. A Federal Judicial Center study of summary judgment examining data in six districts found that the "overall rate at which summary judgment motions are filed has increased since 1975." JOE S. CECIL, DEAN P. Miletich \& George Cort, Fed. Judicial Ctr., Trends in Summary Judgment PracTICE: A PRELIMINARy ANALysis, 3 (2001), available at http://www.fjc.gov/public/pdf.nsf/ lookup/summjudg.pdf/\$file/summjudg.pdf. The $17 \%$ number reflects a set of terminated cases that include cases with little or no judicial involvement. Many cases just "evaporate" without a determinative motion filing. 
Disposition rates for Rule 56 motions can be controversial; critics of summary judgment attack what they think is a tendency to grant summary judgment too readily in civil rights cases. ${ }^{165}$ The percentage of grants of summary judgment in civil rights cases for 2006 was $70 \%$, the highest number of any major type of case in the FJC study of summary judgment. ${ }^{166}$ As to the disposition of antitrust summary judgment motions, $53 \%$ were granted and $47 \%$ were denied. ${ }^{167}$ This rate of summary judgment grants approximates that of tort claims, where an almost identical $54 \%$ of motions were granted, and it is not far from the rate of granting summary judgment requests for all civil cases, $60 \% .{ }^{168}$ It should be noted that the grant data includes a summary judgment motion granted in whole or in part, thereby contributing to what might appear to be a higher percentage of Rule 56 motion grants.

While care should be taken when assessing the use of summary judgment in antitrust litigation, there is reason to employ Rule 56 in complex cases generally and antitrust cases in particular. Treble damages and statutory attorneys fees create a substantial incentive to file antitrust claims, including some claims that may be marginal. The heavy costs of complex and document dominated antitrust litigation can be diminished if a motion for summary judgment is appropriately granted. Conversely, the early denial of a motion for summary judgment can efficiently send a case down the well-worn settlement track.

The timing norms relevant to summary judgment permit early motions in order to interject some efficient substantive assessment of the merits before a case becomes mature. Defendants may request summary judgment "at any time," 169 and plaintiffs may also move with dispatch by requesting summary judgment twenty days after filing an action or any time after the defense moves for summary judgment. ${ }^{170}$ Although the present draft of Rule 56 tolerates late summary judgment motions, ${ }^{171}$ the recent amendment to Rule 56, taking effect December 1, 2009, limits the time to file to thirty days following the close of discovery. ${ }^{172}$

165. See, e.g., Elizabeth M. Schneider, The Dangers of Summary Judgment: Gender and Federal Civil Litigation, 59 Rutgers L. Rev. 705, 709-11 (2007) (discussing the "danger" of excessive rates of granting summary judgment in gender discrimination cases); Wald, supra note 14, at 1897-98 (asserting that summary judgment has assumed a larger role than intended). For a thorough empirical study of summary judgment, see generally Stephen B. Burbank, Vanishing Trials and Summary Judgment in Federal Civil Cases: Drifting Toward Bethlehem or Gomorrah?, 1 J. EMPIRICAL LEGal STUd. 591 (2004).

166. Cecil \& Cort, supra note 161 , at 6.

167. Id. at 7.

168. Id. at 6 .

169. FED. R. CIV. P. 56(b).

170. FED. R. Civ. P. 56(a). Under amendments to Rule 56 which, take effect December 1,2009 , the timing norm has been simplified by permitting summary judgment to be filing "at any time until 30 days after the close of discovery." See infra note 172.

171. See, e.g., FED. R. Civ. P. 56(b) (allowing summary judgment to be sought by defendants "at any time"); FED. R. CIV. P. 56(a) (limiting the time for plaintiffs to file summary judgment requests only within the first twenty days after case filing).

172. Order: Amendments to the Federal Rules of Civil Procedure, Rule 56(c)(1)(A) (2009), available at http://www.supremecourtus.gov/orders/courtorders/frcv09.pdf. 
Summary judgment can be used to resolve various issues in antitrust litigation. It may be a means to decide the viability of antitrust affirmative defenses or to eliminate critical proof requirements from the prima facie case of the plaintiff. A brief review of particular Rule 56 use in antitrust cases reveals a broad and varied use of summary judgment in antitrust litigation.

\section{a. Antitrust Affirmative Defenses}

Substantive antitrust rules set forth several defenses that seem to beg for some sort of pretrial assessment. Because these are affirmative defenses, the moving party must demonstrate that the record supports summary judgment on the issue involved; the movant carries a heavy burden of production, and the light burden of summary judgment production set forth by Celotex Corp. v. Catrett is inapplicable. ${ }^{173}$ If this burden is met, then the nonmovant may not be able to successfully come forward showing disputed issues for trial. This means that antitrust affirmative defenses constitute "killer motions," meaning they have the capacity to end the litigation.

The state action defense is illustrative. Although state action issues can raise complex factual issues, they often involve no issues of fact and constitute pure issues of law. In such a context, the grant of a defense motion for summary judgment based upon state action is common, efficient, and particularly within the expertise of the district court.

Michigan Paytel Joint Venture v. City of Detroit ${ }^{\mathbf{1 7 4}}$ is a good example. There, the defendant city moved for summary judgment on the ground that it was immune from antitrust exposure because of state action immunity. ${ }^{175}$ The Sixth Circuit affirmed summary judgment and dismissed the plaintiffs' claim alleging a conspiracy in bidding for a prison telephone system. ${ }^{176}$ The focus of the state action defense is largely upon issues of law, namely whether the restraint alleged is "clearly articulated and affirmatively expressed as state policy" and that the policy alleged to be illegal has been " 'actively supervised' by the state."177 Where the dispute is purely one under the two-part Midcal Aluminum test, summary judgment motions are essentially legal and can be granted and would appear to be a time-saving device squarely within the power of the court rather than the jury. ${ }^{178}$ If, however, a state action defense raised questions of

173. See Celotex Corp. v. Catrett, 477 U.S. 317, 325 (1986) (placing a burden on the moving party not having the burden of proof to merely point to the lack of evidence put forth by the nonmovant).

174. 287 F.3d 527 (6th Cir. 2002).

175. Id. at 531,534 .

176. Id. at $531-32,542$.

177. Cal. Retail Liquor Dealers Ass'n v. Midcal Aluminum, Inc., 445 U.S. 97, 105 (1980).

178. See, e.g., Yeager's Fuel, Inc. v. Pa. Power \& Light Co., 22 F.3d 1260, 1264-65, 1273 (3d Cir. 1994) (affirming in part and reversing in part based upon state action immunity); Bolt v. Halifax Hosp. Med. Ctr., 980 F.2d 1381, 1384 (11th Cir. 1993) (reversing a trial court denial of summary judgment and characterizing "the question of [state action] immu- 
disputed historical fact unrelated to the two-part Midcal Aluminum framework, summary judgment would appear to be unworkable.

\section{b. Defense Attacks on Elements of the Plaintiff's Prima Facie Case}

A common defense strategy in antitrust litigation is to move for summary judgment, attacking a key element of the plaintiff's case. It is not uncommon to see a motion for summary judgment filed by a defendant who contends that the plaintiff has failed to show disputed issues of fact regarding antitrust injury, ${ }_{179}$ antitrust standing, ${ }^{180}$ impact affecting interstate commerce, ${ }^{181}$ lack of injury to business or property, failure to prove a relevant market, ${ }^{182}$ antitrust statutory exemptions, ${ }^{183}$ or lack of antitrust causation. The range of defense possibilities is broad and diverse, making summary judgment a powerful weapon in defending antitrust actions.

Recent grants of defendant motions for summary judgment illustrate the transsubstantive approach taken by contemporary courts. Judges have granted summary judgment in tying cases because the nonmovant plaintiff was unable to prove appreciable economic power in the market for the tying product, ${ }^{184}$ they have affirmed summary judgment for defendants due to a plaintiff's inability to prove conspiracy through e-mail communications, ${ }^{185}$ and they have affirmed summary judgment because the plaintiff failed to demonstrate sufficient evidence of antitrust

nity . . [as] strictly one of law"); Mobile County Water, Sewer \& Fire Prot. Auth. v. Med. Area Water \& Sewer Sys., Inc., No. 07-0357-WS-M, 2008 WL 4012956, at *1 (S.D. Ala. Aug. 26, 2008) (granting summary judgment based upon state action immunity).

179. See, e.g., Doctor's Hosp. of Jefferson, Inc. v. Se. Med. Alliance, Inc., 123 F.3d 301, 303 (5th Cir. 1997) (affirming summary judgment for the defendant because of a lack of proof of injury to competition in a claim against a health plan); Balaklaw v. Lovell, $14 \mathrm{~F} .3 \mathrm{~d}$ 793, 795, 802 (2d Cir. 1994) (affirming summary judgment for defendants based upon rack of antitrust injury in a claim brought by an anesthesiologist).

180. See, e.g., Sullivan v. Tagliabue, 828 F. Supp. 114, 120 (D. Mass. 1993), aff'd, 25 F.3d 43 (1st Cir. 1994) (affirming summary judgment because of plaintiff's lack of standing); Malamud v. Sinclair Oil Corp., 521 F.2d 1142, 1152 (6th Cir. 1975) (affirming a denial of summary judgment based upon plaintiff's ability to show antitrust standing).

181. See, e.g., Stone v. William Beaumont Hosp., 782 F.2d 609, 615 (6th Cir. 1986) (affirming, in part, summary judgment for the defendants because the plaintiff could not show injury to interstate commerce).

182. See, e.g., Thurman Indus., Inc. v. Pay 'N Pak Stores, Inc., 875 F.2d 1369, 1373, 1380 (9th Cir. 1989) (affirming summary judgment in an antitrust conspiracy case because plaintiff failed to demonstrate injury in a relevant market).

183. See, e.g., Bell v. Fur Breeders Agric. Coop., 348 F.3d 1224, 1235 (10th Cir. 2003) (affirming summary judgment for defendants in a suit brought against an agricultural co-op and concluding that defendants' conduct "fall[s] squarely within the antitrust exemptions in the Clayton and Capper-Volstead Acts").

184. See, e.g., Ticket Ctr., Inc v. Banco Popular De Puerto Rico, No. 04-2062 (GAG/ BJM) 2008 WL 4820544, at *7, 15 (D.P.R. Oct. 31, 2008) (granting defendant's summary judgment because of a lack of proof of a market for the tying product).

185. See, e.g., Golden Bridge Tech., Inc. v. Motorola, Inc., 547 F.3d 266, 272-73 (5th Cir. 2008) (holding summary judgment proper because plaintiff had not shown evidence of an agreement). 
injury. ${ }^{186}$

\section{CONNECTING THE PROCEDURAL DOTS? THE APPLICATION OF THE QUICK LOOK APPROACH TO SUMMARY JUDGMENT}

\section{A. The Importance of TeXaco InC. v. Dagher}

In Texaco Inc. v. Dagher, the Supreme Court reversed a Ninth Circuit decision that imposed per se liability on a geographically-confined joint venture between Texaco and Shell. ${ }^{187}$ The succinct, unanimous opinion of Justice Thomas rejected the use of the per se rule because Shell and Texaco had joined forces as a single entity that was incapable of fixing prices. ${ }^{188}$ This decision contributes to summary judgment jurisprudence by reinstating the grant of summary judgment ordered by the trial court that had dismissed the case on grounds similar to those of the Court. ${ }^{189}$

In a footnote of some methodological significance, Dagher integrated the quick look approach into summary judgment mechanics. ${ }^{190}$ In response to the plaintiffs' contention that Texaco and Shell should be liable under the quick look "doctrine," Justice Thomas seemingly endorsed some kind of quick look approach by observing that they "have applied the quick look doctrine to business activities that are so plainly anticompetitive that courts need undertake only a cursory examination before imposing antitrust liability." 191 Although the Dagher decision fails to use the quick look to impose per se liability, its footnote clearly signals that lower courts can integrate the quick look into summary judgment by granting a plaintiff's motion for summary judgment when confronted with an alleged restraint that, upon "cursory examination," is naked or plainly anti-competitive. ${ }^{192}$

This apparent blessing in Dagher of the use of both the quick look and antitrust summary judgment is all the more significant because of the lessthan-strong endorsement given the quick look in California Dental. 193 There, the Court's cautionary attitude prompted it to reject the quick look application of the court of appeals. ${ }^{194}$ While this litigation involved review of a Federal Trade Commission (FTC) decision and did not entail summary judgment, it displayed a "go slow" treatment of antitrust methodology at odds with the shortcut nature of summary judgment philoso-

186. See, e.g., Hilton v. Children's Hosp. San Diego, No. 07-55467, 2008 WL 4951707, at *1 (9th Cir. Nov. 18, 2008) (noting that the nonmovant radiologist proffered no proof on the impact upon price or the quality of care).

187. Texaco Inc. v. Dagher, 547 U.S. 1, 3, 8 (2006).

188. Id. at 5,6 .

189. See id. at 4.

190. Id. at 7 n.3.

191. Id.

192. See id.

193. See Cal. Dental Ass'n v. FTC, 526 U.S. 756, 770 (1999).

194. See id. at 781. 
phy. ${ }^{195}$ Although Dagher's quick look footnote is brief and fairly tepid, it is significant for not following California Dental and for eschewing skepticism toward the quick look. ${ }^{196}$ The footnote does cite California Dental but in a positive way, as an example of how that quick look is used. ${ }^{197}$ It is almost as though Justice Thomas intentionally dropped a gratuitous footnote in order to rehabilitate the quick look from its seeming trashing in the California Dental decision and, in so doing, may have ignored the negative treatment given the quick look by the Court in California Dental.

Opponents of the quick look might posit that the Dagher footnote was limited to use of the quick look as a tool to impose per se liability. It is true that this positive Dagher response to the quick look ignored its potential use by firms accused of antitrust wrongdoing. Yet, the footnote may have been a targeted response to the argument of the plaintiffs that per se liability should apply through the use of the "quick look doctrine."198 If so, then it would seem logical of Justice Thomas to confine the thrust of his quick look footnote to the argument advanced by the plaintiffs.

\section{B. Integrating Summary Judgment and the Quick LoOK}

While it is possible for the quick look and summary judgment to apply independently, it seems logical for these similar shortcuts to operate together in a sort of integrated tandem arrangement. Nevertheless, decisions to combine these methods may ultimately depend upon the precise goal of the party seeking a quick look. Three distinct strategic litigation options exist. First, the antitrust plaintiff who seeks a quick look in order to force a court to consider applying a per se rule will often want a judgment of pretrial liability. ${ }^{199}$ In this context, the plaintiff will probably move for summary judgment. In contrast, some defendants who want a quick look may hope that application of this methodology will slow the adjudicatory process to activate a full-blown plenary trial. The latter context appears inappropriate for summary judgment. A third possibility is represented by a defendant who is confident that application of the quick look will lead to a follow-up Rule 56 motion based on the efficiencies proved by a quick look. This defendant may advance quick look proof within the summary judgment process. Of course, I acknowledge that

195. See id. at 779.

196. See Texaco Inc., 547 U.S. at 7 n.3.

197. See id.

198. See id.

199. See, e.g., id. (explaining quick look as a "cursory examination" of restraint alleged to identify whether it is "plainly anticompetitive"); Major League Baseball Props., Inc. v. Salvino, Inc., 542 F.3d 290, 334 (2d Cir. 2008) (describing and rejecting the argument of defendant counterclaimant that plaintiff's conduct was illegal per se under quick look approach); Gen. Leaseways, Inc. v. Nat'l Truck Leasing Ass'n, 744 F.2d 588, 595 (7th Cir. 1984) (calling for an abbreviated examination of an alleged horizontal market division to determine the applicability of a per se rule). 
some defense counsel will want to bypass the quick look altogether and seek judgment based upon the rule of reason.

Summary judgment's trial-like, adjudicative, pretrial nature constitutes an effective means to utilize the quick look method. The process of taking a pretrial quick look at the anti-competitive and pro-competitive impact of an alleged restraint involves expert affidavits and arguments, the hallmarks of summary judgment procedure. 200 Accordingly, a tandem approach combining summary judgment and the quick look would integrate expert affidavits supporting and opposing illegality and constitute the "meat and potatoes" of both summary judgment and quick look mechanics.

The integration of antitrust summary judgment and the quick look is quite predictable and straightforward. One combination of these shortcuts involves an antitrust plaintiff who moves for summary judgment and argues that the alleged restraint is so plainly anti-competitive after a quick look that the motion should be granted. The district court grant of summary judgment in Continental Airlines, Inc. v. United Airlines, Inc. is illustrative. ${ }^{201}$ There, the trial court emphasized the "defendants' inability to offer any plausible or material procompetitive justifications for their agreement to restrict the size of carry-on baggage at Dulles [airport]."202 The quick look method is one-dimensional in such cases and calls for summary judgment to be granted where there is an obvious anticompetitive effect and the record reveals a lack of any plausible pro-competitive justifications. ${ }^{203}$

I do not predict that many motions for summary judgment using the quick look will be granted. Few quick look applications result in a grant of a Rule 56 motion. With the increased unwillingness to employ per se rules and courts' fear of reversal due to failure to develop the record, grants of such plaintiffs' Rule 56 motions occur infrequently. Courts find that use of the per se and quick look "standards are exceptional ... and their application is reserved for the most patently anticompetitive restraints."204 Reversing the trial court's grant of summary judgment in Continental Airlines, the Fourth Circuit boldly asserted that "courts have

200. See Edward Brunet, The Use and Misuse of Expert Testimony in Summary Judg. ment, 22 U.C. DAVIs L. REV. 93, 93-95 (1988) (describing an increase in the use of expert affidavits and the need to satisfy admissibility standards to consider expert affidavits).

201. See Continental Airlines, Inc. v. United Airlines, Inc., 126 F. Supp. 2d 962, 976, (E.D. Va. 2001), rev'd, 277 F.3d 499 (4th Cir. 2002).

202. Id. at 981 .

203. See, e.g., Clarett v. NFL, 306 F. Supp. 2d 379, 408-09 (S.D.N.Y. 2004) (asserting that the NFL draft eligibility "[r]ule is the perfect example of a policy that is appropriately analyzed under the 'quick look' standard because its anticompetitive effects are so obvious" and concluding that defendant NFL "failed to offer any legitimate procompetitive justifications"), rev'd on other grounds, 369 F.3d 124, 125 (2d Cir. 2004); Law v. NCAA, 902 F. Supp. 1394, 1405, 1410 (D. Kan. 1995) (applying quick look to grant summary judgment for plaintiff). Inquiry into whether the proof is "obvious" is central to summary judgment and was the basis of modern summary judgment's historical antecedent, trial by inspection. See Brunet, supra note 129, at 1625.

204. Craftsmen Limousine, Inc. v. Ford Motor Co., 491 F.3d 380, 387 (8th Cir. 2007). 
been wary of summary judgment in the context of quick-look analysis."205 In addition, courts are likely to reject application of the quick look approach in cases alleging violations in a vertical restraints context, which appear wholly dependent on the rule of reason. ${ }^{206}$

The role of appellate review influences the reluctance to grant a defense summary judgment motion based upon a quick look. A district judge is never reversed for undertaking too thorough an evidentiary examination of an alleged restraint. In contrast, courts of appeal do reverse based upon the use of shortcuts such as summary judgment or the quick look method. ${ }^{207}$ Such reversals serve to deter summary judgment grants using a quick look approach.

A second and more common integration of the quick look and summary judgment involves a quick look analysis followed by a district court grant of summary judgment dismissing the case. For example, in Blubaugh v. American Contract Bridge League, the trial court used a quick look framework to grant summary judgment and dismiss the plaintiff's boycott claim. ${ }^{208}$ Note that it is possible that the defendant movant will not seek quick look treatment, but instead might argue for application of a full-dress rule of reason. ${ }^{209}$

Other procedural means capable of combining the quick look and summary judgment exists. The combination of a sua sponte quick look analysis followed by a sua sponte summary judgment is clearly justifiable under the extremely broad Rule 16 pretrial powers of district judges. ${ }^{210}$ Rule 16 pretrial conferences hold the potential to play an important role in quick look methodology. Rule 16(c)(2)(D) specifically permits the court to avoid "unnecessary proof," and Rule 16(c)(2)(A) allows the court discretionary power to engage in "formulating and simplifying the issues."211 Read liberally, these powers under Rule 16 would seemingly justify a district judge's decision to apply the quick look method, a procedure that

205. Continental Airlines, Inc. v. United Airlines, Inc., 277 F.3d 499, 511 (stressing the need for a full rule of reason examination and, citing California Dental Ass'n v. FTC, 526 U.S. 756, 762-63, condemning the district court's treatment as "too quick an analysis on an insufficiently developed factual record").

206. See, e.g., Jame Fine Chems., Inc. v. Hi-Tech Pharm. Co., No. 00-3545 (AET), 2007 WL 927976, at*4 (D.N.J. Mar. 27, 2007) (granting summary judgment of antitrust claims and rejecting quick look because violations alleged were vertical in nature and, therefore, to be analyzed under the rule of reason).

207. See, e.g., Dagher v. Saudi Ref., Inc., 369 F.3d 1108, 1120-21 (9th Cir. 2004), rev'd, 547 U.S. 1 (2006); Rossi v. Standard Roofing, Inc., 156 F.3d 452, 463 (3d Cir. 1998); Am. Ad Mgmt., Inc. v. GTE Corp., 92 F.3d 781, $791-92$ (9th Cir. 1996); Denny's Marina, Inc. v. Renfro Prods., Inc., 8 F.3d 1217, 1222 (7th Cir. 1993).

208. See Blubaugh v. Am. Contract Bridge League, No. IP 01-358-C H/K, $2004 \mathrm{WL}$ 392930 , at $* 17, * 19$ (S.D. Ind. Feb. 18, 2004).

209. See, e.g., Gordon v. Lewistown Hosp., 423 F.3d 184, 209-10 (3d Cir. 2005) (affirming a district judge who refused to use the quick look approach in a monopolization claim brought by a physician and granted summary judgment for defendant hospital using rule of reason).

210. See, e.g., FED. R. CIV. P. 16(c)(2)(I) (empowering a trial judge to employ special procedures in managing complex cases).

211. FED. R. Civ. P. 16(c)(2)(A), (D). 
would simplify the case and eventually avoid unnecessary proof. Alternatively, the district court has explicit authority under Rule 16(c)(2)(E) to consider granting a motion for summary judgment as part of the pretrial process. ${ }^{212}$ These powers, together with the extremely broad authority to act in a just, speedy, and cost-conscious manner under Rule $16(c)(2)(P),{ }^{213}$ permit further efficient integration of the quick look and summary judgment in the pretrial phase of litigation.

\section{The Use of the Quick Look at the Federal Trade Commission}

The FTC, an agency operating with its own version of a summary judgment rule, ${ }^{214}$ has used the quick look method with mixed success in multiple opinions. No FTC case uses its "summary decision" rule in tandem with a quick look approach. In Massachusetts Board of Optometry, the FTC set forth a thoughtful elaboration of the quick look that focused upon proof of obvious harm to consumers, which shifted a burden upon defendant to produce plausible, pro-competitive justifications either with beneficial consumer impact or without causing adverse consequences to the market at issue. ${ }^{215}$ In California Dental, the FTC used the quick look to find illegal advertising restrictions set by defendants. ${ }^{216}$ In PolyGram Holding, the FTC concluded that the defendants' restriction on marketing, while not per se illegal, appeared close to a presumptively illegal naked restraint. ${ }^{217}$ More recently, in North Texas Specialty Physicians, the FTC used the quick look to hold illegal price polling and information sharing among independent physicians. ${ }^{218}$ These opinions, particularly the more recent PolyGram and North Texas Specialty Physician decisions, demonstrate a commitment by the FTC to continue its attempt to use a shortcut methodology, even in the aftermath of the adverse treatment of the quick look in the 1999 California Dental decision. ${ }^{219}$

212. FED. R. CIV. P. 16(c)(2)(E).

213. FED. R. CIV. P. 16(c)(2)(P).

214. See 16 C.F.R. \$ 3.24 (2009) (making available a motion for "summary decision" where there is no dispute as to the facts presented). For FTC applications of its summary disposition rule, see, for example, In re PolyGram Holding, Inc., No. 9298, 2002 WL 31433923 , at *1, *3 (F.T.C. Feb. 26, 2002) (denying defendants' motion for summary disposition because the issue whether the alleged moratorium on discounted recordings was essential and necessary created an issue of fact for trial); In re Telebrands Corp., No. 9313, 2004 WL 1720010, at *1-2 (F.T.C. Apr. 13, 2004) (denying the Commission's motion for summary decision in a false claims dispute and explaining that FTC "applies its summary decision rule consistent with case law construing Fed. R. Civ. P. 56").

215. In re Mass. Bd. of Optometry, 110 F.T.C. 549, 1988 WL 1025476, at *39 (June 13, 1988). If the defendant meets this burden, then the burden shifts back to the FTC to explain, without added proof, the anti-competitive nature of the alleged restraint. Id.

216. In re Cal. Dental Ass'n, 121 F.T.C. 190298, 307 (1996), aff'd 128 F.3d 720 (9th Cir. 1997), vacated, 526 U.S. 756 (1999).

217. In re PolyGram Holding, Inc., No. 9298, 2003 WL 21770765 (F.T.C. July 24, 2003), aff'd, 416 F.3d 29 (D.C. Cir. 2005).

218. In re N. Tex. Specialty Physicians, 2005-2 Trade Cases If 75,032 (2005), remanded on other grounds, 528 F.3d 346, 352 (5th Cir. 2008).

219. See Calkins, supra note 27 , at 556 (rationally predicting that future FTC decisions will avoid the term "quick look"). 
The FTC has used the quick look concept often since the early 1980s. The earliest application of the quick look by the agency characterized the quick look as a version of the rule of reason, referring to the methodology as a "truncated or so-called 'quick look' rule of reason that considers whether any possible procompetitive justifications might exist."220 These FTC applications of the quick look were not limited to the rule of reason. Cases exist demonstrating how the Commission has used the quick look to help decide a wide variety of issues. In a merger case involving disputed entry barriers, Commissioner Patricia Bailey concluded that the " 'quick look' test leads to a rule of per se legality for many mergers." 221 In a case involving minimum fees and uniform interpreter charges, the FTC used the quick look approach to assess the market share and consumer ability to switch to alternative suppliers. ${ }^{222}$

In addition to continuing to find utility in the quick look in litigation, the FTC, along with the Department of Justice, has emphasized the quick look methodology in its Antitrust Guidelines for Competitor Collaboration Among Competitors (Guidelines), issued in 2000.223 The Guidelines set forth a multi-tiered continuum of methods for antitrust analysis, including per se, the rule of reason, the doctrine of ancillary restraints, and a broad reading of the quick look. Where an alleged restraint is deserving of rule of reason treatment, the Guidelines call for quick look evaluation. 224 This approach avoids the detailed evidence of pro-competitive justifications unless there exists real evidence of anti-competitive impact.

The quick look test set forth by the Guidelines offers a separate "reach" efficiency not involved in a tandem application of summary judgment and the quick look. ${ }^{225}$ The quick look process represents a selfapplied antitrust analysis usually detached from litigation. Under this procedure, the quick look reaches many business practices that are never litigated and allows a less expensive way to self-evaluate, rather than litigate, competitive impact. ${ }^{226}$

220. See In re Borg-Warner Corp., 101 F.T.C. 863 (1983); accord Am. Soc'y of Internal Med., 105 F.T.C. 505 (1985) (referring to the quick look as a proper "method of analysis [that] can be deemed a truncated quick-look, or limited rule of reason analysis"); In re Echlin Mfg. Co., 105 F.T.C. 410, 1985 WL 668902 (F.T.C.), June 28, 1985 (referring to a shortcut examination of barriers to entry in a merger dispute as a "truncated, quick-look, or limited rule of reason analysis").

221. See In re Echlin Manufacturing Co, 105 F.T.C. 410 (1985) (Bailey, Comm'r, dissenting).

222. In re Int'l Ass'n of Conference Interpreters, 123 F.T.C. 465, 587 (1997) (using the quick look to assess market share held by defendants and to establish anticompetitive impact ).

223. See FTC \& DeP'T of Justice, supra note 68 , at $4,10-11$.

224. See Gavil ET AL., supra note 43, at 209 (stating that the Guidelines can be used to exonerate liability where the absence of market power and the nature of the alleged restraint demonstrate the absence of anti-competitive injury).

225. See FTC \& DEP'T OF JUSTICE, supra note 68, at 14-15.

226. See id. 


\section{CONCLUSION}

The quick look methodology lacks an express and certain definition. Some describe it as a mere synonym for per se illegality and others equate it to an abbreviated version of the rule of reason. Some authorities consider the quick look a middle ground while, in contrast, respected commentators place it on a continuum of methodologies.

Clarity regarding the quick look is a scarce commodity. Although the Supreme Court has been neither explicitly complimentary nor explanatory regarding the quick look methodology, it nonetheless has failed to invalidate the approach. ${ }^{227}$ The 2006 Dagher footnote flirts with the quick look as though the earlier California Dental opinion had not exposed the shortcomings of the procedure. ${ }^{228}$ In brief, uncertainty reigns regarding the continued viability and meaning of the quick look at our highest court. Meanwhile, use of the quick look continues unabated at the FTC with repeated reliance on the quick look over a decades-long period. 229

At the same time, another procedural shortcut, summary judgment, seems in good form in antitrust litigation, despite the presence of volumes of documents and critical intent issues. The non-transsubstantive Poller dictum, expressing reluctance to use summary judgment in antitrust litigation, appears to have been ignored in older decisions, such as Cities Service, and put to death in the Matsushita decision. ${ }^{230}$ We are presently in an era of broad and increasing summary judgment use that reflects judicial willingness to employ the procedure in antitrust cases. The existing empirical evidence suggests that summary judgment motions are more likely to be filed in antitrust cases $(23 \%)$ than the mean filing rate $(17 \%) .^{231}$ This fact should cause analysts to rightly ponder antitrust summary judgment and, at the same time, incentivize defendants, the usual beneficiaries of a Rule 56 grant, to file a summary judgment motion.

A robust antitrust summary judgment practice is very relevant to the quick look method. A brief line of published cases integrates summary judgment with the quick look to dismiss cases revealed to be plainly anticompetitive after a quick look at the alleged restraint. ${ }^{232}$ In contrast, several other cases apply the quick look as a prelude to dismissing antitrust claims through a motion for summary judgment. ${ }^{233}$ Neither of these sets of cases is large; quantitatively, the combination of quick look and summary judgment, while high on interest and potential, yields little quantitative volume. The FTC continues to consider the quick look as a viable

227. See supra section III.A.

228. See supra notes $190-97$ and accompanying text.

229. See supra section III.C.

230. See supra notes $92,94,126$ and accompanying text.

231. See supra note 164.

232. See, e.g., Continental Airlines, Inc. v. United Airlines, Inc., 126 F. Supp. 2d 962 (E.D. Va. 2001), rev'd, 277 F.3d 499 (4th Cir. 2002).

233. See, e.g., Blubaugh v. Am. Contract Bridge League, No. IP 01-358-C H/K, 2004 WL 392930 (S.D. Ind. Feb. 18, 2004). 
test but, in a manner similar to the courts,' has failed to integrate its summary disposition into the mechanics of a quick look approach. ${ }^{234}$

In short, there is much theoretical synergy between quick look and summary judgment but, thus far, only a modest quantity of real-world results in published cases. Perhaps the quick look and summary judgment procedures are too similar and tend to confuse those seeking shortcuts in complex litigation. At the end of the day, it may be asking too much to integrate a venerated procedure, summary judgment, with an ambiguous and substantive rule of analysis-the quick look. ployed the quick look). 